\title{
Feasibility in the echocardiographic estimation of parameters of the right ventricle in prone position
}

\section{Factibilidad en la estimación ecocardiográfica de parámetros del ventrículo derecho en posición prono}

\author{
Luis E. Santos-Martínez ${ }^{1,2 *}$, Gastón Mendoza-Copaㄹ, Edgar García-Cruz¹, Rolando J. Álvarez-Álvarez, \\ Rafael E. Bucio-Reta1 , Francisco J. González-Ruiz', Ángel Ramos-Enríquez', \\ Miguel Á. Hernández-Márquez ${ }^{1}$, and Francisco M. Baranda-Tovar ${ }^{1}$
}

${ }^{1}$ Department of Cardiovascular Post-Surgical Intensive Care, Instituto Nacional de Cardiología Ignacio Chávez, Secretaría de Salubridad y Asistencia, Mexico City, Mexico; ${ }^{2}$ Department of Pulmonary Hypertension and Right Heart, High Specialty Medical Unit, Cardiology Hospital, Centro Médico Nacional Siglo XXI, Instituto Mexicano del Seguro Social, Mexico City, Mexico

\begin{abstract}
Background: Echocardiographic cardiac parameters in the prone position are usually obtained with an esophageal probe. The feasibility of obtaining them by means of a transthoracic approach is unknown. Objective: Estimating the feasibility to obtain parameters of the right ventricle by transthoracic echocardiography in prone position on the subject. Methods: Pilot design of consecutive case series without cardiopulmonary disease. Demographic, vital signs and echocardiographic variables were defined in the ventral initial, prone and ventral final decubitus positions. The data are shown with averages and standard deviations, and frequencies and percentages according to the variable. The differences between the positions were calculated with ANOVA of repeated samples and adjustment of Bonferroni test. Intra-subject variability was obtained by the Bland-Altman procedure and its $95 \%$ confidence interval. Results: We studied 50 subjects, $44(88 \%)$ males, age $30 \pm 6$ years and body mass index $25.65 \pm 2.71 \mathrm{~kg} / \mathrm{m}^{2}$. Tricuspid annular plane systolic excursion (TAPSE) and S'-wave were measured $100 \%$ of the time. The vital signs and echocardiographic variables according to the position had differences in: heart rate $(74 \pm 9$ vs. $77 \pm 9$ vs. $75 \pm 8$ beats/min), partial oxygen saturation (94.40 \pm 1.70 vs. $96.64 \pm 1.79$ vs. $95.32 \pm 1.36 \%)$ and mean systemic blood pressure ( $65.33 \pm 5.38$ vs. $67.69 \pm 6.31$ vs. 65.29 $\pm 5.62 \mathrm{mmHg}) ;$ TAPSE $(19.74 \pm 3.24 \mathrm{vs} .21 .60 \pm 2.97 \mathrm{vs} .19 .44 \pm 2.84 \mathrm{~mm})$, mean difference (bias) $0(2,-2.0)$ and S'-wave (13.52 \pm 1.87 vs. $15.02 \pm 2.09$ vs. $13.46 \pm 1.55 \mathrm{~cm} / \mathrm{s})$, mean difference (bias) $-0.46(1.21,-2.14)$ respectively. Conclusions: Obtaining right ventricle parameters by transthoracic ecocardiopraphy is feasible in the prone position.
\end{abstract}

Key words: Patient positioning. Transthoracic echocardiography. Ultrasonography. Diagnostic image. Hemodynamics.

\section{Resumen}

Introducción: Los parámetros cardiacos ecocardiográficos en posición de decúbito prono usualmente se obtienen con sonda esofágica. Se desconoce la factibilidad de obtenerlos mediante aproximación transtorácica. Objetivo: Estimar la factibilidad para obtener parámetros del ventrículo derecho mediante ecocardiografía transtorácica en el sujeto en posición de decúbito prono.

Correspondence:

*Luis E. Santos Martínez

E-mail: luis.santos@ cardiologia.gob.mx
Available online: 04-09-2020 Arch Cardiol Mex (Eng). 2020;90(2):116-123 www.archivoscardiologia.com 2604-7063 / @ 2019 Instituto Nacional de Cardiología Ignacio Chávez. Published by Permanyer. This is an open access article under the CC BY-NC-ND license (http://creativecommons.org/licenses/by-nc-nd/4.0/). 
Métodos: Diseño piloto de serie de casos consecutivos sin enfermedad cardiopulmonar. Se acotaron variables demográficas, signos vitales y ecocardiográficas en posición decúbito ventral inicial, prono y ventral final. Los datos se muestran con promedios y desviaciones estándar, y frecuencias y porcentajes de acuerdo con la variable. La diferencia entre las posiciones se calculó con ANOVA de muestras repetidas y ajuste de Bonferroni. Se obtuvo la variabilidad intrasujetos mediante el procedimiento de Bland-Altman y su intervalo de confianza al 95\%. Resultados: Se estudiaron 50 sujetos, 44 (88\%) masculinos, edad $30 \pm 6$ años e índice de masa corporal $25.65 \pm 2.71 \mathrm{~kg} / \mathrm{m}^{2}$. El TAPSE (excursión sistólica del plano del anillo tricuspídeo) y la onda S' se midieron en el $100 \%$ de las veces. Los signos vitales y variables ecocardiográficas de acuerdo con la posición tuvieron diferencias en: frecuencia cardiaca ( $74 \pm 9$ vs. $77 \pm 9$ vs. $75 \pm 8 \mathrm{lpm}$ ), saturación parcial de oxígeno ( $94.40 \pm 1.70 \mathrm{vs.} 96.64 \pm 1.79 \mathrm{vs}$. $95.32 \pm 1.36 \%)$ y la presión arterial sistémica media (65.33 \pm 5.38 vs. $67.69 \pm 6.31$ vs. $65.29 \pm 5.62 \mathrm{mmHg})$; TAPSE $\left(19.74 \pm 3.24\right.$ vs. $21.60 \pm 2.97$ vs. 19.44 vs. $2.84 \mathrm{~mm}$ ), diferencia media (sesgo) $0(2,-2.0)$ y onda $S^{\prime}(13.52 \pm 1.87$ vs. $15.02 \pm 2.09$ vs. $13.46 \pm 1.55 \mathrm{~cm} / \mathrm{s}$ ), diferencia media (sesgo) $-0.46(1.21,-2.14)$ respectivamente. Conclusión: En posición de decúbito prono es factible obtener parámetros del ventrículo derecho por ecocardiografía transtorácica.

Palabras clave: Posición del paciente. Ecocardiografía transtorácica. Ultrasonografía. Imagen diagnóstica. Hemodinamia.

\section{Introduction}

The prone decubitus (PD) or ventral decubitus position is an anatomical position of the human body characterized by lying face down keeping the patient's head sideways and the neck in neutral position.

This position is commonly used in medical-surgical procedures, such as nephrolithotomy ${ }^{1}$, endoscopic retrograde cholangiopancreatography ${ }^{2}$, and in posterior fossa surgeries of the head, neck, vertebrae, retroperitoneum, and posterior body structures in case of plastic surgery ${ }^{3,4}$.

In intensive care units, the PD position has been used as part of adult respiratory distress syndrome (ARDS) treatment ${ }^{5-7}$. With this position, an improvement has been defined in oxygenation, pulmonary mechanics, pulmonary ventilation/perfusion (V/Q) ratio, and as a pulmonary protection maneuver in these patients ${ }^{5-7}$; the effect on mortality is still questioned, although a meta-analysis that included 12 works and 2129 patients showed a mortality decrease with the use of PD for more than $12 \mathrm{~h}^{8}$.

In ARDS, study and treatment have focused on the evaluation of pulmonary vascular damage, and the goals have been "lung opening" and arterial oxygen saturation optimization ${ }^{9}$.

With the new knowledge about pathophysiology in ARDS and with better non-invasive methods to assess the right ventricle (RV) as transthoracic echocardiography (TTE) does, hemodynamic aspects have acquired higher relevance, specifically the development of acute cor pulmonale ${ }^{10}$, which appears to be involved in mortality.

TTE assessment is usually carried out in dorsal decubitus (supine) or lateral position, since it does not interfere with the position of the transducer ${ }^{11,12}$; however, in the PD position, the anterior chest wall is obstructed and, therefore, having useful windows to carry out RV estimations appears to be limited.

Hence, in this work, as a first approach to the entity, we studied subjects without cardiopulmonary disease in PD position to know the feasibility of having adequate acoustic windows to determine RV parameters with TTE.

\section{Methods}

The work was carried out at the Postsurgical Cardiovascular Intensive Care Department (Postsurgical Therapy [PST]) of the Ignacio Chávez National Institute of Cardiology, from March 1, 2018, to December 31, 2018.

\section{Study design}

Pilot study, case series, and consecutive subjects who were admitted to the PST department and agreed to participate were studied.

\section{Inclusion and exclusion criteria}

Subjects of both genders, older than 18 years and without cardiopulmonary disease were included in the study. Subjects with acoustic window alterations were excluded from the study. Those with incomplete studies or studies of poor quality for analysis were censored.

To obtain partial oxygen saturation $\left(\mathrm{SpO}_{2}\right)$, the same pulse oximeter was used in all subjects: Ony $x^{\circledR}$ II Model 9550 (Nonin Medical INC., Plymouth, Minnesota, USA). 


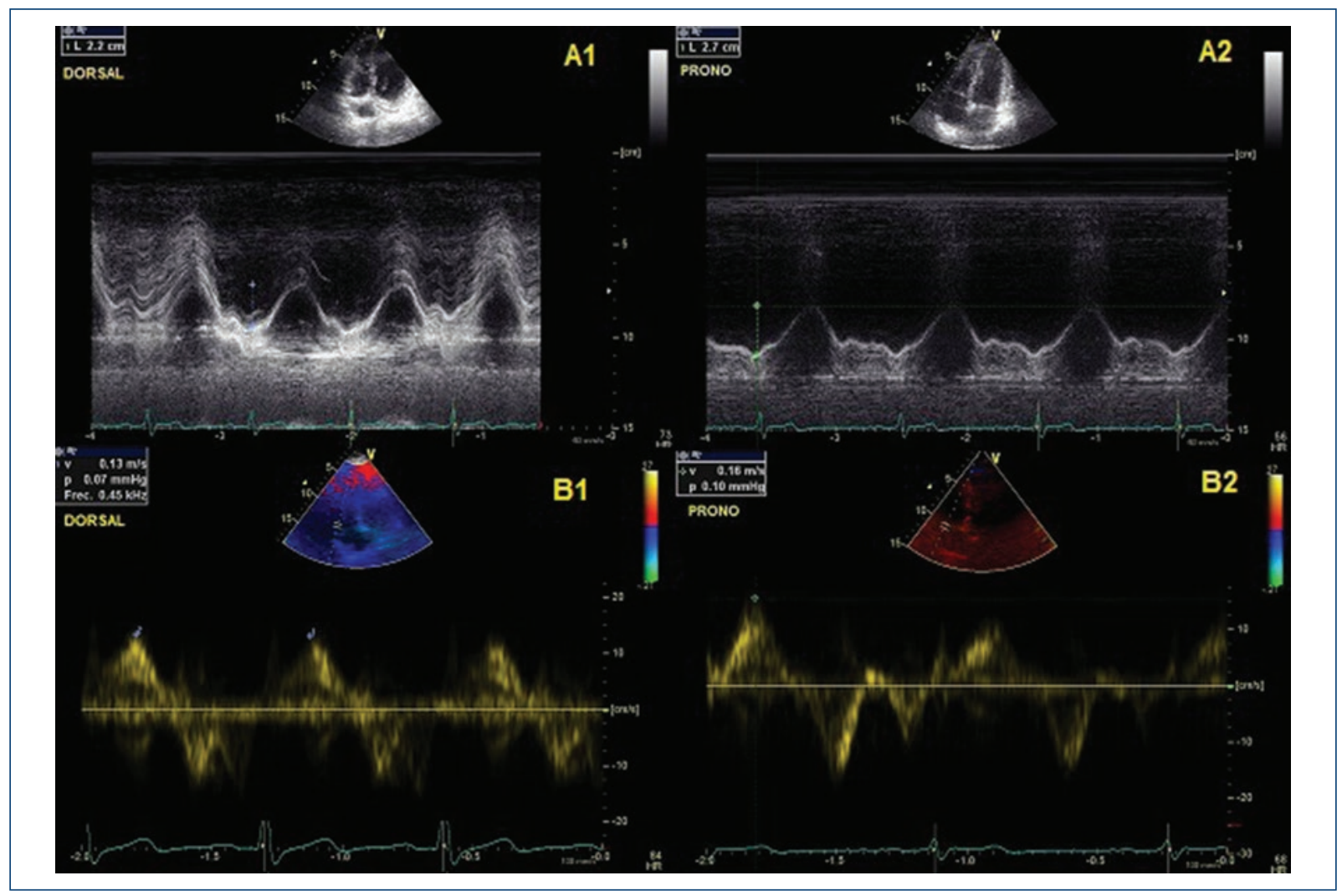

Figure 1. Tricuspid annular plane systolic excursion (TAPSE) echocardiographic images in dorsal decubitus (A1), prone decubitus (A2), and $S^{\prime}$-wave in dorsal decubitus (B1), prone decubitus (B2). Dorsal and prone decubitus TAPSE, in M mode and measured in $\mathrm{mm}$. S'-wave, with tissue Doppler, measured in $\mathrm{cm} / \mathrm{s}$.

Systemic blood pressure (BP) was obtained with a Phillips ${ }^{\circledR}$ MP 70 pneumatic sphygmomanometer. Due to the slim build of all patients, the same standard bracelet was used on the right arm, with a $12 \times 26-\mathrm{cm}$ camera.

The echocardiography equipment used in all cases was the cardiovascular ultrasound system VIVID ${ }^{\circledR} \mathrm{E} 9$, with M5S-D ${ }^{\circledR}$ sector heart probe (GE Vingmed Ultrasound A/S, Norten, Norway), with 1.5-4.6-MHz transducer, and images were obtained with tissue harmonic imaging. No echographic contrast medium was used to improve endocardial edges visualization.

All echocardiographic parameters were acquired by the same researcher (General Medical Council); the second evaluation, intended to establish intra-observer agreement with regard to parameters, was carried out $24 \mathrm{~h}$ after the first ones were estimated.

Echocardiographic parameters were quantified according to the guidelines published by the American Society of Echocardiography for assessment of the right heart ${ }^{11,12}$ : tricuspid annular plane systolic excursion (TAPSE), calculated in M-mode in the four-chamber apical plane, measured in millimeters (Fig. 1A1 and A2); tricuspid $S^{1}$-wave, lateral systolic tricuspid annular tissue velocity, using tissue Doppler in the four-chamber apical plane measured in $\mathrm{cm} / \mathrm{s}$, (Fig. 1B1 and B2); RV fractional area change (FAC, \%), obtained from RV end-diastolic area in relation to RV systolic area in four-chamber projection, measured as a percentage; pulmonary artery systolic pressure (PAP-s) was calculated with the tricuspid insufficiency $(\mathrm{TI})$ gradient using Bernoulli's simplified equation: TI ${ }^{2} \times 4+$ RAP (right atrial pressure) inquired in a four-chamber projection with continuous Doppler, estimated in $\mathrm{mmHg}$; RV/left ventricle (LV) ratio, quantified in four-chamber projection at diastole.

Subject's PD positioning required for him/her to remain lying face down with the head turned to the side and the neck in neutral position; in addition, the left arm was positioned in the upward direction (toward the head) and a $10-\mathrm{cm}$-height pillow was placed in the ventral infraclavicular region, which allowed for a better image to be obtained (Fig. 2). The transducer was 


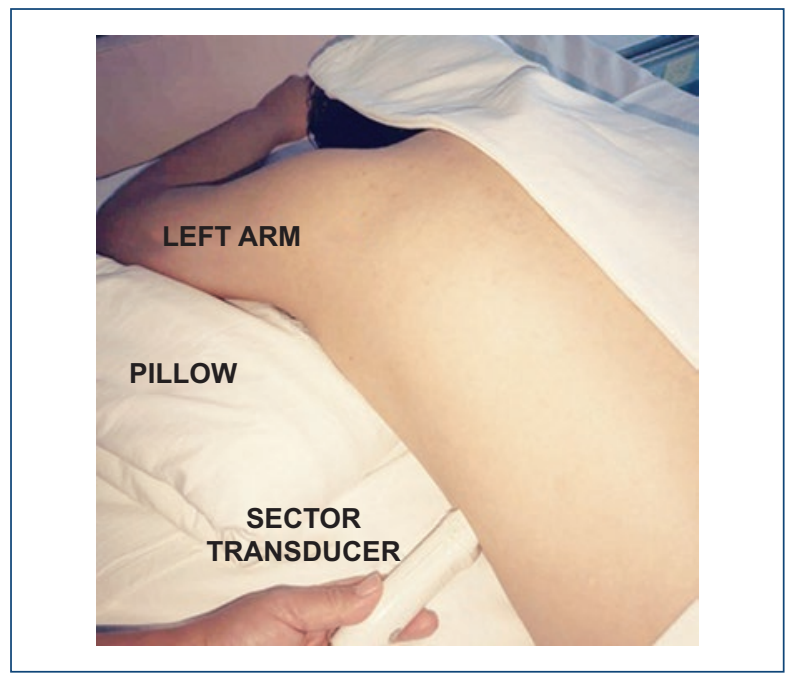

Figure 2. Prone decubitus position used to obtain the echocardiographic variables.

placed between the $4^{\text {th }}$ and $5^{\text {th }}$ left intercostal space toward the anterior axillary line. With this position, the aforementioned variables could be obtained in the PD position. This position is a modification of the swimmer position used in an intensive care unit in case transesophageal echocardiography is not available ${ }^{13}$.

\section{Maneuver}

Once the study subject had been selected according to the inclusion criteria, he/she was placed in the dorsal decubitus (supine) position and the referred echocardiographic variables and vital signs were determined; then, 10 min later, the subject was placed in the PD position and the same images were obtained for echocardiographic analysis and recording of the same vital signs; finally, the subject returned to his/her final dorsal decubitus position and, 10 min later, all variables were estimated again. A third participant, blinded to the measurements, collected the results, and recorded them in the database.

\section{Statistical analysis}

Data are presented as averages \pm standard deviation for numerical data, and as frequencies and percentages for nominal data. The analysis of between-group differences was performed using repeated measures ANOVA with Bonferroni's adjustment. A $p<0.05$ was considered statistically significant. Intra-subject agreement was analyzed for the estimated RV parameters with Bland-Altman's statistic al method ${ }^{14}$, and its magnitude was calculated using the intraclass correlation coefficient ${ }^{15}$ with its $95 \%$ confidence interval $(\mathrm{Cl})$.

Since this was a pilot study to assess the feasibility of estimating parameters, a convenience sample of 50 subjects was used.

The study was approved by the Research and Ethics Committee of the Ignacio Chávez National Institute of Cardiology, and all subjects signed an informed consent letter before the echocardiography study.

\section{Results}

Fifty subjects without cardiopulmonary disease were studied. Average age was $30 \pm 6$ years, the male/female ratio was 44/6; weight, $77.33 \pm 10.85 \mathrm{~kg}$; height, $1.73 \pm 0.07 \mathrm{~m}$; body surface area, $1.91 \pm 0.16 \mathrm{~m}^{2}$; and body mass index, $25.65 \pm 2.71 \mathrm{~kg} / \mathrm{m}^{2}$.

Vital signs behavior according to the inquired position is shown in table 1.

Echocardiographic variables in the dorsal and PD position are listed in table 2. The frequency at which acquiring the inquired variables were possible according to initial dorsal decubitus, supine decubitus and final dorsal decubitus position was, respectively: TAPSE 50 (100\%), 50 (100\%), 50 (100\%); FAC: 50 (100\%), 44 (88\%), 50 (100\%); RVDA 50 (100\%), 44 (88\%), and 49 (98\%); RVSA: 50 (100\%), 44 (88\%), 49 (98\%); PAP-s $35(70 \%), 38(76 \%)$, and 39 (78\%); S' wave: $50(100 \%)$, 50 (100\%), 50 (100\%), and RV/LV ratio: 50 (100\%), 46 $(92 \%)$, and $50(100 \%)$.

Intra-observer agreement for echocardiographic variables in the dorsal and supine position is shown in table 3. Fig. 3 shows TAPSE as the echocardiographic variable with the lowest variability in both positions.

\section{Discussion}

The purpose of the present work was to know, through TTE, the feasibility to estimate RV parameters related to its systolic function ${ }^{11,12}$ in the PD position in subjects without cardiopulmonary disease.

The study population had an average age of 30 years, were more frequently males and the body mass index was normal or overweight; with no cardiopulmonary disease.

Vital signs behavior in the study population was as follows: there were small differences in heart rate $(\mathrm{HR})$ from ventral decubitus to $\mathrm{PD}$ position and returned to baseline HR when the subjects were moved back to the ventral decubitus position, $p<0.014$ (Table 1). 
Arch Cardiol Mex (Eng). 2020;90(2)

Table 1. Vital signs behavior in baseline dorsal decubitus, prone, and final dorsal decubitus position

\begin{tabular}{|c|c|c|c|c|}
\hline & Dorsal decubitus $X \pm S D$ & Prone decubitus $X \pm S D$ & Dorsal decubitus $X \pm$ SD & $\mathbf{p}$ \\
\hline $\mathrm{HR}, \mathrm{bpm}$ & $74 \pm 9$ & $77 \pm 9$ & $75 \pm 8$ & $\begin{array}{c}1 \text { vs. } 2=0.014 \\
2 \text { vs. } 3=0.45 \\
1 \text { vs. } 3=0.789\end{array}$ \\
\hline $\mathrm{RR}$, brpm & $14 \pm 1$ & $14 \pm 1$ & $14 \pm 1$ & $\begin{array}{c}1 \text { vs. } 2=0.686 \\
2 \text { vs. } 3=1.00 \\
1 \text { vs. } 3=0.871\end{array}$ \\
\hline $\mathrm{SpO}_{2}, \%$ & $94.40 \pm 1.70$ & $96.64 \pm 1.79$ & $95.32 \pm 1.36$ & $\begin{array}{l}1 \text { vs. } 2=0.001 \\
2 \text { vs. } 3=0.001 \\
1 \text { vs. } 3=0.001\end{array}$ \\
\hline $\mathrm{SBP}, \mathrm{mmHg}$ & $124.12 \pm 11.75$ & $126 \pm 11.24$ & $123.88 \pm 11.07$ & $\begin{array}{c}1 \text { vs. } 2=0.402 \\
2 \text { vs. } 3=0.132 \\
1 \text { vs. } 3=1.00\end{array}$ \\
\hline $\mathrm{DBP}, \mathrm{mmHg}$ & $71.86 \pm 8.23$ & $74.06 \pm 9.53$ & $72 \pm 7.70$ & $\begin{array}{c}1 \text { vs. } 2=0.154 \\
2 \text { vs. } 3=0.099 \\
1 \text { vs. } 3=1.00\end{array}$ \\
\hline $\mathrm{MBP}, \mathrm{mmHg}$ & $65.33 \pm 5.38$ & $67.69 \pm 6.31$ & $65.29 \pm 5.62$ & $\begin{array}{l}1 \text { vs. } 2=0.037 \\
2 \text { vs. } 3=0.050 \\
1 \text { vs. } 3=0.680\end{array}$ \\
\hline
\end{tabular}

HR: heart ratio; bpm: beats per minute; RR: respiratory rate; brpm: breaths per minute; SBP: systolic blood pressure; DBP: diastolic blood pressure; M: mean; X: mean; $\mathrm{SD}$ : standard deviation; $\mathrm{SpO}_{2}$ : partial oxygen saturation.

Table 2. Echocardiographic variables behavior in baseline dorsal decubitus, prone, and final dorsal decubitus positions.

\begin{tabular}{|c|c|c|c|c|}
\hline & Dorsal decubitus $X \pm S D$ & Prone decubitus $X \pm S D$ & Dorsal decubitus $X \pm$ SD & p \\
\hline TAPSE, mm & $19.74 \pm 3.24$ & $21.60 \pm 2.97$ & $19.44 \pm 2.84$ & $\begin{array}{l}1 \text { vs. } 2=0.001 \\
2 \text { vs. } 3=0.001 \\
1 \text { vs. } 3=0.749\end{array}$ \\
\hline $\mathrm{S}^{\prime}$-wave, $\mathrm{cm} / \mathrm{s}$ & $13.52 \pm 1.87$ & $15.02 \pm 2.09$ & $13.46 \pm 1.55$ & $\begin{array}{c}1 \text { vs. } 2=0.001 \\
2 \text { vs. } 3=0.001 \\
1 \text { vs. } 3=1.00\end{array}$ \\
\hline RV FAC, $\%$ & $42.14 \pm 5.78$ & $45.73 \pm 5.72$ & $43.02 \pm 4.66$ & $\begin{array}{l}1 \text { vs. } 2=0.001 \\
2 \text { vs. } 3=0.004 \\
1 \text { vs. } 3=0.188\end{array}$ \\
\hline $\mathrm{RV}$ area at diastole, $\mathrm{cm}^{2}$ & $17.25 \pm 2.04$ & $17.58 \pm 2.18$ & $17.09 \pm 1.88$ & $\begin{array}{l}1 \text { vs. } 2=1.00 \\
2 \text { vs. } 3=0.312 \\
1 \text { vs. } 3=0.833\end{array}$ \\
\hline $\mathrm{RV}$ area at systole, $\mathrm{cm}^{2}$ & $9.98 \pm 1.73$ & $9.58 \pm 1.63$ & $9.74 \pm 1.50$ & $\begin{array}{l}1 \text { vs. } 2=0.613 \\
2 \text { vs. } 3=1.00 \\
1 \text { vs. } 3=0.227\end{array}$ \\
\hline PASP $\mathrm{mmHg}$ & $16.40 \pm 6.01$ & $15.89 \pm 5.24$ & $15.74 \pm 4.69$ & $\begin{array}{l}1 \text { vs. } 2=1.00 \\
2 \text { vs. } 3=1.00 \\
1 \text { vs. } 3=0.775\end{array}$ \\
\hline $\mathrm{RV} / \mathrm{LV}$ & $0.74 \pm 0.12$ & $0.76 \pm 0.11$ & $0.75 \pm 0.12$ & $\begin{array}{l}1 \text { vs. } 2=0.156 \\
2 \text { vs. } 3=0.154 \\
1 \text { vs. } 3=0.950\end{array}$ \\
\hline
\end{tabular}

X: mean; SD: standard deviation; TAPSE: tricuspid annular plane systolic excursion; FAC: fractional area change; RV: right ventricle; LV: left ventricle; PASP: pulmonary artery systolic pressure; RV/LV: right ventricle-left ventricle ratio.

As for respiratory rate $(\mathrm{RR})$, there were no modifications with position changes, unlike $\mathrm{SpO}$, which increased when changing from ventral decubitus to $\mathrm{PD}$ position and returned to baseline level when the subject was returned to ventral decubitus position $(p=0.001)$ (Table 1). 
Table 3. Echocardiographic variables mean difference behavior, bias, intraclass correlation coefficient, and 95\% confidence interval in dorsal and prone positions

\begin{tabular}{|l|c|c|c|c|}
\hline \multirow{2}{*}{} & \multicolumn{2}{|c|}{ Dorsal decubitus } & \multicolumn{2}{c|}{ Prone decubitus } \\
\cline { 2 - 5 } & Mean difference (bias) & ICC (95\% CI) & Mean difference (bias) & ICC (95\% CI) \\
\hline TAPSE, mm & $0(2,-2.0)$ & $0.976(0.950,0.988)$ & $0.1(2,-1.9)$ & $0.974(0.947,0.987)$ \\
\hline S'-wave, cm/s & $-0.46(1.21,-2.14)$ & $0.954(0.907,0.968)$ & $0.2(1.8,-1.4)$ & $0.963(0.923,0.982)$ \\
\hline RV FAC, \% & $0.1(6,-5.8)$ & $0.944(0.882,0.973)$ & $0.9(8.3,-6.5)$ & $0.891(0.757,0.951)$ \\
\hline RV area at diastole, cm ${ }^{2}$ & $0.23(1.44,-0.98)$ & $0.981(0.959,0.991)$ & $0.6(3.9,-2.7)$ & $0.862(0.691,0.938)$ \\
\hline RV area at systole, cm ${ }^{2}$ & $0.17(1.44,-1.11)$ & $0.973(0.944,0.987)$ & $0.4(2.6,-1.9)$ & $0.884(0.741,0.948)$ \\
\hline PASP, mm Hg & $-0.1(5.3,-5.6)$ & $0.954(0.892,0.981)$ & $-0.8(5.2,-6.9)$ & $0.945(0.878,0.976)$ \\
\hline RV/LV & $0.01(0.17,-0.14)$ & $0.856(0.698,0.932)$ & $0.02(0.19,-0.15)$ & $0.796(0.558,0.905)$ \\
\hline
\end{tabular}

ICC: intraclass correlation coefficient; Cl: confidence interval; TAPSE: tricuspid annular plane systolic excursion; FAC: fractional area change; RV: right ventricle; PASP: pulmonary artery systolic pressure; RV/LV: right ventricle-left ventricle ratio.

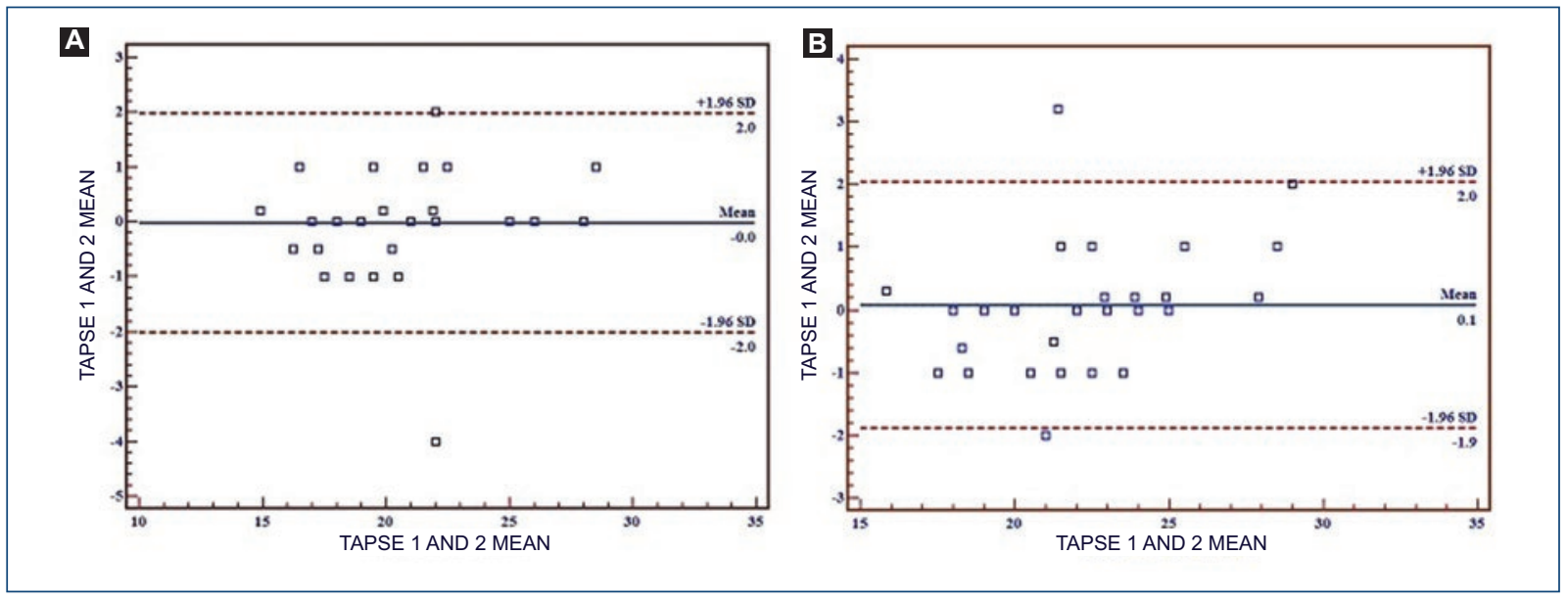

Figure 3. Tricuspid annulus plane systolic excursion mean difference and bias in dorsal decubitus (A) and prone position (B). SD: standard deviation.

There were no changes detected in systolic and diastolic BP; however, mean BP had discreet increases with the change from initial decubitus ventral to the $P D$ position ( $p=0.037)$ and from PD to ventral $(p=0.050)$, by means of which it equaled initial mean BP (Table 1).

Hemodynamic changes were associated with body position changes, as it has been previously referred in the field of anesthesia when adopting the PD position $^{1-4,16,17}$. These changes reflect heart preload and afterload alterations.

Furthermore, these same body position changes cause differences in lung volumes and, therefore, in pulmonary $V / Q$, which is reflected in a better pulmonary $V / Q$ ratio and its effect on gas exchange, which in our work was shown by a better $\mathrm{SpO}_{2}$ (better oxygen saturation).

This work was not designed to describe the pathophysiology of possible changes in vital signs or hemodynamics in the prone position; however, making some considerations about what could be occurring is possible. These vital signs discreet alterations appear to be related to the complex interaction that breath and circulation maintain ${ }^{18-20}$.

Changes have been described with breaths at normal tidal volume ${ }^{18}$ and not necessarily with the RR sole increase, which would support the lack of response in RR found in our results; in pathological states, this behavior can be more evident and deleterious ${ }^{19}$. 
Changes in lung volume inspiratory/expiratory phases and intrathoracic pressure (ITP) during normal respiratory cycle alter right and left heart preload and afterload, whereupon they interact to vary cardiac output and BP with the respiratory cycle ${ }^{20}$.

During the inspiratory phase of respiration, while the alveoli are filled with air, ITP decreases, and favors systemic venous return toward the chest; the right heart fills up and blood is pumped into the pulmonary artery, which dilates to accommodate the flow. In two to three beats, blood reaches the LV and BP increases at the end of inspiration and beginning of expiration, whereupon BP slightly decreases at inspiration and increases during expiration; this effect can be enhanced or counteracted by the sudden increase of blood flow to the LV during inspiration ${ }^{18,21}$. In addition, mean BP transient increase with the PD position can be a reflection of the decrease in venous return (preload) induced by the position ${ }^{16,17}$.

In pathological conditions, these alterations can favor ventricular interdependence mechanisms ${ }^{18,19}$.

In the PD position, determining by TTE the parameters shown in table 2 was possible. This study also shows that it is possible to determine some parameters related to RV systolic function, which in theory would enable determining them in subjects with ARDS, which will be subject of another study.

Intra-subject variability with regard to the enquired indices is small, specifically for TAPSE and the S'-wave, and $100 \%$ of the time they could be measured; this small TAPSE variability has already been previously reported in another context ${ }^{22}$.

These RV echocardiographic parameters are modified according to position changes, specifically when adopting the PD position, and could be related to the preload alterations induced by position modification ${ }^{19-21}$.

\section{Limitations}

In this work, the purpose of knowing the feasibility of obtaining images for RV systolic function analysis was met. However, the estimation was carried out in subjects without cardiopulmonary disease and not on mechanical ventilation, as it occurs in patients with ARDS $^{5,6}$. Furthermore, the sample was restricted to young patients, with the highest body mass index being overweight.

Nevertheless, this work shows that at least the PD position is not entirely a limitation to obtain these images and estimating RV echocardiographic parameters, which makes TTE a suitable, non-invasive tool to assess the moment when a patient with ARDS experiences cor pulmonale and opt for pronation; and conversely, also the moment the cor pulmonale disappears and the PD position is no longer required for patient improvement.

\section{Conclusions}

TTE is a useful tool for determining parameters related to RV systolic function. In the PD position, obtaining TTE images is possible to make a consistent and feasible analysis of RV systolic function.

Changes in vital signs and RV parameters estimated by TTE were associated with position changes.

\section{Funding}

The authors declare that they did not receive any sponsorship to carry out this article.

\section{Conflicts of interest}

The authors declare that they have no conflicts of interest.

\section{Ethical disclosures}

Protection of people and animals. The authors declare that the procedures followed were in compliance with the ethical standards of the committee responsible for human experimentation and in accordance to the World Medical Association and the Declaration of Helsinki.

Confidentiality of data. The authors declare that they have followed the protocols of their work center on the publication of patient data.

Right to privacy and informed consent. The authors have obtained informed consent from the patients and/or subjects referred to in the article. This document is in the possession of the corresponding author.

\section{References}

1. Mourmouris P, Berdempes M, Markopoulos T, Lazarou L, Tzelves L, Skolarikos A. Patient positioning during percutaneous nephrolithotomy: what is the current best practice? Res Rep Urol. 2018;10:189-93.

2. Mashiana HS, Jayaraj M, Mohan BP, Ohning G, Adler DG. Comparison of outcomes for supine vs. prone position ERCP: a systematic review and meta-analysis. Endosc Int Open. 2018;6(11):E1296-301.

3. DePasse JM, Palumbo MA, Haque M, Eberson CP, Daniels AH. Complications associated with prone positioning in elective spinal surgery. World J Orthop. 2015;6(3):351-9.

4. Kwee MM, Yik-Hong $H$, Rozen WM. The prone position during surgery and its complications: A systematic review and evidence-based guidelines. Int Surg. 2015;100:292-303.

5. Rialp-Cervera G. Efectos del decúbito prono en el síndrome de distrés respiratorio agudo (SDRA). Med Intensiva. 2003;27(7):481-7. 
6. Martínez O, Nin N, Esteban A. Evidencias de la posición en decúbito prono para el tratamiento del síndrome de distrés respiratorio agudo: una puesta al día. Arch Bronconeumol. 2009;45(6):291-6.

7. Bos LD, Martin-Loeches I, Schultz MJ. ARDS: challenges in patient care and frontiers in research. Eur Respir Rev. 2018;27(147).

8. Munshi L, Del Sorbo L, Adhikari NKJ, Hodgson CL, Wunsch H, Meade MO et al. Prone position for acute respiratory distress syndrome. A systematic review and meta-analysis. Ann Am Thorac Soc. 2017;14(Suppl 4):S280-8.

9. Rawal G, Yadav S, Kumar R. acute respiratory distress syndrome: an update and review. J Transl Int Med. 2018;6(2):74-7.

10. Repessé $X$, Charron $C$, Vieillard-Baron A. Acute cor pulmonale in ARDS: rationale for protecting the right ventricle. Chest. 2015;147(1):259-65.

11. Rudski LG, Lai WW, Afilalo J, Hua L, Handschumacher MD, Chandrasekaran K. Guidelines for the echocardiographic assessment of the right heart in adults: a report from the American Society of Echocardiography. J Am Soc Echocardiogr. 2010;23(7):685-713.

12. Wu VC, Takeuchi M. Echocardiographic assessment of right ventricular systolic function. Cardiovasc Diagn Ther. 2018;8(1):70-9.

13. Ugalde D, Medel JN, Romero C, Cornejo R. Transthoracic cardiac ultrasound in prone position: a technique variation description. Intensive Care Med. 2018;44(6):986-7.
14. Bland JM, Altman DG. Statistical methods for assessing agreement between two methods of clinical measurement. Lancet. 1986;1:307-10.

15. Kramer MS, Feinstein AR. Clinical biostatistics LIV. The biostatistics of concordance. Clin Pharmacol Ther.1981:29:111-23.

16. Dharmavaram S, Jellish S, Russ P, Shea J, Mehmood R, Ghanayem A, et al. Effect of prone positioning systems on hemodynamic and cardiac function during lumbar spine surgery: An echocardiographic study. Spine. 2006;31:1388-93.

17. Edgcombe $\mathrm{H}$, Carter $\mathrm{K}$, Yarrow $\mathrm{S}$. Anaesthesia in the prone position. $\mathrm{Br}$ J Anaesth. 2008;100:165-83.

18. Cheifetz IM. Cardiorespiratory interactions: The relationship between mechanical ventilation and hemodynamics. Resp Care 2014:59:1937-45.

19. Pinsky MR. Heart-lung interactions. Curr Opin Crit Care. 2007;13:528-31.

20. Bronicky RA, Anas NG. Cardiopulmonary interaction. Pediatr Crit Care. 2009;10:313-22

21. Pinsky MR. Cardiovascular issues in respiratory care. Chest. 2005; 128:592S-97S.

22. Olmos-Temois SG, Santos-Martínez LE, Álvarez-Álvarez R, Gutiérrez-Delgado LG, Baranda-Tovar FM. Interobserver agreement on the echocardiographic parameters that estimate right ventricular systolic function in the early postoperative period of cardiac surgery. Med Intensiva. 2016;40:491-98. 